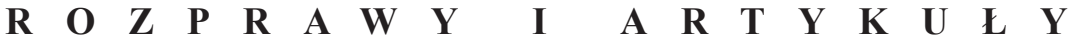

Prawo Kanoniczne

55 (2012) nr 1

KS. ARKADIUSZ DOMASZK SDB

Uniwersytet Kardynała Stefana Wyszyńskiego w Warszawie

\section{REALIZACJA MISJI KOŚCIOLA W STOWARZYSZENIACH ZWIĄZANYCH Z DUCHOWOŚCIĄ TOWARZYSTWA ŚW. FRANCISZKA SALEZEGO}

Treść: Wstęp. - 1. Prawo polskie. - 2. Prawo kanoniczne. - 3. Stowarzyszenia w historii i prawie własnym Towarzystwa św. Franciszka Salezego. - 4. Salezjańskie Stowarzyszenie Wychowania Młodzieży. -5. Salezjański Ruch Troskio Młodzież Saltrom. - 6. Salezjańska Organizacja Sportowa Rzeczypospolitej Polskiej. - Zakończenie.

\section{Wstęp}

Prawodawstwo polskie szanuje prawo do stowarzyszania się. Pośród wielu różnych polskich stowarzyszeń znajdują się także te, które są związane z duchowością i celami konkretnych instytutów zakonnych. Istnieją m.in. stowarzyszenia nawiązujące do charyzmatu salezjańskiego, które opierają się na duchowości Towarzystwa św. Franciszka Salezego ${ }^{1}$. Niniejsza praca badawcza odniesie się do tych właśnie stowarzyszeń istniejących w Polsce. Stowarzyszenia mogą realizować różnorodne cele. Badanie skupi się na kwestii: jak działalność wybranych stowarzyszeń nawiązuje do realizacji celów Towarzystwa Salezjańskiego, a zarazem misji całego Kościoła.

Zauważenie zadań Kościoła podejmowanych w wybranych stowarzyszeniach łączy się z rozważeniem również norm prawa kanonicznego. Dlatego wyżej określony cel badawczy zostanie odniesiony do

1 Zamiennie z pełną nazwą „Towarzystwo św. Franciszka Salezego” używam nazwy skróconej „Towarzystwo Salezjańskie” lub „Zgromadzenie Salezjańskie”. W tradycji instytutu określenie ,,prowincja zakonna” zastępowane jest terminem ,,inspektoria”, a „prowincjał”- ,inspektorem”. Fundamentalne prawo własne salezjanów składa się z dwóch zbiorów, por. Konstytucje i Regulaminy Ogólne Towarzystwa św. Franciszka Salezego, Rzym 1986, dalej cytuję Konstytucje lub Regulaminy Ogólne. 
prawa polskiego, jak i do prawa kanonicznego, a w dalszej kolejności do prawa własnego Towarzystwa św. Franciszka Salezego.

Przedmiotem badań będą następujące podmioty: Salezjańskie Stowarzyszenie Wychowania Młodzieży, Salezjański Ruch Troski o Młodzież Saltrom, Salezjańska Organizacja Sportowa Rzeczypospolitej Polskiej. Nie są to wszystkie stowarzyszenia, które nawiązują do duchowości salezjańskiej i działają na terenie Polski. Niniejszy artykuł ukazuje jedynie przykładowe stowarzyszenia oraz to, jak w założeniach i w praktyce realizują one cele eklezjalne. Tytułem wprowadzenia, w punkcie pierwszym zostanie pokrótce przybliżone prawo polskie nt. stowarzyszeń. Następnie zaprezentowane zostaną normy prawa kanonicznego dotyczące stowarzyszania się oraz prawo własne salezjanów, które zawiera możność współpracy z różnymi stowarzyszeniami. W kolejnych punktach zostaną omówione wymienione wyżej stowarzyszenia, nawiązujące do duchowości salezjańskiej.

\section{Prawo polskie}

W demokratycznym społeczeństwie obywatelskim w swobodny sposób tworzą się liczne stowarzyszenia. Stanowią one ważną część sektora organizacji pozarządowych o celach niezarobkowych ${ }^{2}$. Podstawowe oparcie znajdują w prawie konstytucyjnym. Prawo do stowarzyszania się należy do praw człowieka. Także Konstytucja Rzeczypospolitej Polskiej gwarantuje to prawo: ,Rzeczpospolita Polska zapewnia wolność tworzenia i działania (...) stowarzyszeń (...)"3. Prawo to występuje również w Konstytucji w dziale wolności i praw politycznych: „każdemu zapewnia się wolność zrzeszania się"4.

Szczegółowe normy nt. stowarzyszeń zawiera ustawa $\mathrm{z}$ dnia 7 kwietnia 1989 r. Prawo o stowarzyszeniach ${ }^{5}$. Stowarzyszenie jest do-

2 Por. H. Izdebski, Fundacje i stowarzyszenia. Komentarz, orzecznictwo, skorowidz, wyd. 12, Krasnobród 2004, s. 9-19.

${ }^{3}$ Konstytucja Rzeczypospolitej Polskiej z dnia 2 kwietnia 1997 r., Dz. U. z 1997 r., nr 78 , poz. 483 , art. 12 .

${ }^{4}$ Tamże, art. 58 ust. 1; „Zakazane są zrzeszenia, których cel lub działalność są sprzeczne z Konstytucją lub ustawą. (...) Ustawa określa rodzaje zrzeszeń podlegających sądowej rejestracji, tryb tej rejestracji oraz formy nadzoru nad tymi zrzeszeniami.", tamże, art. 58 ust. 2-3.

5 Por. Dz. U. z 1989 r., nr 20, poz. 104 z późn. zm. (dalej Prawo o stowarzyszeniach). Por. komentarze do Prawa o stowarzyszeniach: H. IzDEBSKI, Fundacje i stowarzyszenia; P. Suski, Stowarzyszenia i fundacje, Warszawa 2005. 
browolną korporacją osób, które wspólnie chcą realizować określone przez siebie zadania. „Stowarzyszenie jest dobrowolnym, samorządnym, trwałym zrzeszeniem o celach niezarobkowych"6. Wszystkie istotne elementy, które tworzą stowarzyszenie, zawiera statut, a zwłaszcza: nazwę własną, teren działania i siedzibę, cele, kwestię członkostwa, władze stowarzyszenia i sposób jego reprezentacji, posiadany majątek, nanoszenie zmian w statucie i sposób rozwiązania ${ }^{7}$. Stowarzyszenie podlega obowiązkowi wpisu do Krajowego Rejestru Sądowego (KRS) ${ }^{8}$. Po rozpoznaniu przez właściwy sąd i wpisaniu do wspomnianego Rejestru uzyskuje osobowość prawną ${ }^{9}$. Do zasadniczych władz w stowarzyszeniu należą: walne zebranie członków, zarząd i organ kontroli wewnętrznej ${ }^{10}$.

Ze względu na to, że niniejsze opracowanie zajmuje się także realizacją misji Kościoła, należy zauważyć szczególną grupę stowarzyszeń. Konkordat polski gwarantuje ,prawo wiernych do zrzeszania się zgodnie $\mathrm{z}$ prawem kanonicznym i w celach określonych $\mathrm{w}$ tym prawie" ${ }^{\prime 1}$. Stowarzyszenia wiernych, czy to posiadające kanoniczną podmiotowość prawną, czy też nie, mogą zabiegać o potwierdzenie lub uzyskanie osobowości cywilno-prawnej. Istnieje możliwość uznania podmiotowości w prawie polskim, już posiadanej według prawa kanonicznego, poprzez wypełnienie procedury poinformowania organów władzy państwowej. Tak stanowi Konkordat polski: „inne instytucje kościelne mogą na wniosek władzy kościelnej uzyskać osobowość prawną na podstawie prawa polskiego"12. Procedurę potwierdzenia osobowości prawnej dla publicznych stowarzyszeń wiernych podaje

\footnotetext{
${ }^{6}$ Prawo o stowarzyszeniach, art. 2 ust. 1.

7 Por. tamże, art. 10 ust. 1.

8 Por. tamże, art. 8 ust. 1, art. 12.

9 Por. tamże, art. 17 ust. 1.

${ }_{10}$ Por. tamże, art. 11 ust. 1-3.

${ }^{11}$ Konkordat polski z 28.07.1993, Dz. U. z 1998, nr 51 poz. 318, art. 19. Por. J. KruKowski, Konkordat polski. Znaczenie i realizacja, Lublin 1999, s. 158-162; Prawo wyznaniowe, red. H. Misztal, P. Stanisz, wyd. 2, Lublin 2003, s. 356-365; Prawo wyznaniowe, red. A. Mezglewski, H. Misztal, P. Stanisz, wyd. 2, Warszawa 2008, s. 95-102.

${ }_{12}$ Konkordat polski, art. 4, ust. 3. Wcześniejsze rozwiązania prawne w odniesieniu do kościelnych i katolickich organizacji, por. Ustawa z dnia 17 maja 1989 r. o stosunku Państwa do Kościoła katolickiego w Rzeczypospolitej Polskiej, Dz. U. 1989 r., nr 29, poz. 154 z późn. zm., art. 33-37.
} 
instrukcja Komisji Konkordatowej z 2000 r. ${ }^{13}$. Natomiast prywatne stowarzyszenia wiernych mogą uzyskać podmiotowość prawną poprzez wspomnianą wyżej sądową rejestrację, tj. według ustawy Prawo o stowarzyszeniach ${ }^{14}$. Respektując prawo polskie, wierni mogą się zrzeszać, a dodatkowo poprzez zapis konkordatowy (w art. 19) strona państwowa gwarantuje, że stowarzyszenia wiernych mogą się kierować normami prawa kanonicznego ${ }^{15}$.

\section{Prawo kanoniczne}

Prawodawca kościelny pośród obowiązków i praw wszystkich wiernych umieścił prawo do stowarzyszania się. „Wierni mają prawo swobodnego zakładania stowarzyszeń i kierowania nimi dla celów miłości lub pobożności albo dla ożywiania chrześcijańskiego powołania w świecie, a także odbywania zebrań dla wspólnego osiagnięcia tych celów"16. Kodeks Prawa Kanonicznego z 1983 r. poświęca

13 Por. Kościelna Komisja Konkordatowa, Instrukcja dotyczqca zakresu i sposobu uzyskania osobowości prawnej przez instytucje kościelne na podstawie prawa polskiego, 15.06.2000, Akta Konferencji Episkopatu Polski, nr 5 (2000), Warszawa 2000, s. 41-50. Strona kościelna, za pośrednictwem sekretariatu Konferencji Episkopatu Polski, składa wniosek do Ministerstwa Spraw Wewnętrznych i Administracji; do wniosku dołącza się: kopię dekretu utworzenia stowarzyszenia, uwierzytelniony tekst statutu i informację o danych personalnych osoby prawnej, por. tamże, art. 6-8. Nabycie osobowości zgodnie z prawem polskim dokonuje się na podstawie rozporządzenia Ministra Spraw Wewnętrznych i Administracji, które jest publikowane w Dzienniku Ustaw RP, por. tamże, art. 10-12.

14 Por. tamże, art. 14. Zastosowanie Prawa o stowarzyszeniach do organizacji katolickich, o których mowa w Ustawie z dnia 17 maja 1989 r. o stosunku Państwa do Kościoła katolickiego..., por. H. IzDEBSKI, Fundacje i stowarzyszenia, s. 120-122.

15 Por. J. KruKowsKi, Konkordat polski, s. 159-160.

${ }^{16}$ Kodeks Prawa Kanonicznego. Przekład polski zatwierdzony przez Konferencje Episkopatu, Poznań 1984 (dalej KPK 1983), kan. 215. Por. literaturę nt. prawa wiernych do zrzeszania się: E. SzTafrowski, Podręcznik prawa kanonicznego, t. 1, Warszawa 1985, s. 341-354; T. PAwluk, Prawo kanoniczne wedtug Kodeksu Jana Pawła II, t. 2, Olsztyn 1986, s. 103-110; L. Gerosa, Prawo Kościoła, tłum. I. Pękalski, Poznań 1999, s. 299-316; Komentarz do Kodeksu Prawa Kanonicznego, t. II/1, red. J. Krukowski, Poznań 2005, s. 123-155; M. WróBel, Stowarzyszenia katolickie działajace w Polsce wedtug obowiqzujacego prawa kościelnego, Prawo Kanoniczne 49 (2006) 3-4, s. 122 -131; D. GĄcIK, Prawo wiernych do stowarzyszania się, Kieleckie Studia Teologiczne 8 (2009), s. 31-44; R. BACCARI, Il diritto di associazzione nella Chiesa, w: I laici nel diritti della Chiesa, Citta del Vaticano 1987, s. 57-72; L. NAVArro, Diritto di associazione e assiociazioni di fedeli, Milano 1991, s. 5-33; G. FELICIANI, Il diritto di associazione 
stowarzyszeniom wiernych oddzielny tytu ${ }^{17}$. Normy kodeksowe w sposób istotny opierają się na nauczaniu Soboru Watykańskiego II ${ }^{18}$. Zasadniczą myślą organizującą ich działanie jest to, że stowarzyszenia nie są celem same dla siebie, lecz mają służyć wypełnianiu misji Kościoła ${ }^{19}$.

Wierni poprzez działalność stowarzyszeniową realizują zadania związane z życiem Kościoła katolickiego ${ }^{20}$. Zrzeszeni, choć mogą należeć do różnych stanów, podejmują różnorodne cele: rozwój życia duchowego, publiczny kult, popieranie chrześcijańskiej doktryny, dzieła apostolatu, ewangelizacji, pobożności lub miłości, jak również ożywienie duchem chrześcijańskim porządku doczesnego ${ }^{21}$. Zależnie od potrzeb mogą się pojawić bardziej szczegółowe cele stowarzyszeń, które są złączone z misją Kościoła ${ }^{22}$. W chrześcijańskim widzeniu tego zagadnienia stowarzyszenia powstają z inspiracji Ducha Świętego, który pobudza wiernych do działalności dla dobra Kościoła ${ }^{23}$.

nella Chiesa: autorita, autonomia dei fedeli e comunione ecclesiale, w: Le associazioni nella Chiesa, Citta del Vaticano 1999, s. 19-31; V. Mamertino, Il Diritto di associazione nella Chiesa: fondamento e finalita, Citta del Vaticano 2000; V. DE PAoLIS, Diritto dei fedeli di assiociarsi e la normativa che lo regola, w: Fedeli. Associazioni. Movimenti, XXVIII Incontro di studi ,, Villa Cagnola”- Gazzada 2 luglio-6 luglio 2001, Milano 2002, s. 127-162; C. ReDAELLI, Aspetti problematici della normativa canonica e della sua applicazione alla realta assiociativa della Chiesa, w: tamże, s. 163-185; A. Ferrante, Il Diritto di associarsi dei fedeli, Roma 2003; V. Marano, Il Fenomeno assiociativo nell'ordinamento ecclesiale, Milano 2003.

17 Por. KPK 1983, kan. 298-329.

18 Por. Dekret o apostolstwie świeckich Apostolicam actuositatem, 18.11.1965 r., w: Sobór Watykański II, Konstytucje, Dekrety, Deklaracje, tekst polski, Poznań 2002, s. 377-401, nr 19, 24; Dekret o postudze i życiu kapłanów Presbyterorum ordinis, 07.12.1965 r., w: tamże, s. 478-508, nr 8; G. Feliciani, Il diritto di associazione nella Chiesa, s. 20-22; R. Oliver, Associations of the faithful in the Antepreparatory and Preaparatory phases of Vatican II, The Jurist 70 (2010) 1, s. 86-113.

19 Por. Apostolicam actuositatem, nr 19.

${ }^{20}$ Prawo kanoniczne odróżnia stowarzyszenia wiernych od instytutów życia konsekrowanego i stowarzyszeń życia apostolskiego, co widać także w systematyce kodeksowej, por. KPK 1983, kan. 298 § 1.

${ }^{21}$ Por. tamże, kan. $298 \S 1$. Wierni powinni należeć do tych stowarzyszeń, które władza kościelna erygowała albo zaleca czy popiera, por. tamże, kan. $298 \S 2$.

22 Por. M. Wróbel, Stowarzyszenia katolickie..., s. 159-162.

${ }^{23}$ Por. Komentarz do Kodeksu Prawa Kanonicznego, t. II/1, s. 125. Stowarzyszenia wiernych łączą się z koncepcją ,,charyzmatu”, por. L. Gerosa, Prawo Kościoła, s. 302- 
Prawo kanoniczne dzieli stowarzyszenia na prywatne i publiczne ${ }^{24}$. Stowarzyszenia publiczne powstają, aby realizować cele „w imieniu Kościoła", np. rozwijać kult publiczny ${ }^{25}$; są one wyraźnie erygowane przez władzę kościelną ${ }^{26}$. Istnieją też stowarzyszenia związane z duchowością niektórych instytutów zakonnych, zwane „trzecimi zakonami". Członkowie tych ostatnich pozostają w życiu świeckim, prowadzą określone życie apostolskie i w charyzmacie danego zakonu dążą do doskonałości ${ }^{27}$.

Istotnymi prawnymi elementami konstytuującymi stowarzyszenie jest posiadana nazwa własna i statut. Ten ostatni winien określać: cel, siedzibę, zarząd, sposoby działania, członkostwo i inne konstytutywne czynniki ${ }^{28}$. Prawo kanoniczne poddaje stowarzyszenia wiernych kościelnemu nadzorowi oraz wytycza ogólne normy, np. przyjmowania członków ${ }^{29}$.

Publiczne stowarzyszenia eryguje: Stolica Apostolska, Konferencja Episkopatu i biskup diecezjalny ${ }^{30}$. Zgoda biskupa diecezjalnego na erygowanie domu instytutu zakonnego zawiera w sobie także zezwolenie na założenie w tymże domu lub w złączonym $\mathrm{z}$ nim kościele

307. O historii katolickich polskich stowarzyszeń, por. M. WróBEL, Stowarzyszenia katolickie..., s. 131-143.

24 Por. P. GiUliani, La distinzione fra assiociazioni pubbliche e associazioni private dei fedeli nel nuovo Codice di Diritto Canonico, Roma 1986; L. NAVARro, Le forme tipiche di associazione dei fedeli, w: Le associazioni nella Chiesa, Citta del Vaticano 1999, s. 33-52; M. F. MATERNINI ZotTA, Le associazioni ecclesiali tra publico e privato, w: tamże, s. 53-66; T. RAKOczY, Publiczne stowarzyszenia wiernych $w$ Kodeksie Prawa Kanonicznego z 1983 r., Gniezno 2011.

25 Por. KPK 1983, kan. $301 \S 1$. Podziały stowarzyszeń wiernych, por. L. GERosA, Prawo Kościoła, s. 310-312; M. WróBel, Stowarzyszenia katolickie..., s. 144-149.

${ }^{26}$ Por. KPK 1983, kan. $301 \S 1-2$; L. NAVARro, Diritto di associazione e assiociazioni di fedeli, s. 141-210.

27 Por. KPK 1983, kan. 303. W niektórych stowarzyszeniach nawiązujących do określonego instytutu życia konsekrowanego, osoby konsekrowane pełnią funkcję kierowniczą lub funkcje asystentów oraz zabiegają o włączenie tychże stowarzyszeń w działalność apostolską na terenie diecezji, por. tamże, kan. 311; L. NAVARro, Diritto di associazione e assiociazioni di fedeli, s. 191-194.

${ }^{28}$ Por. KPK 1983, kan. 304 § 1-2, kan. 94 § 1-3; M. WróBEL, Stowarzyszenia katolickie..., s. 151-157.

29 Por. KPK 1983, kan. 305-311.

30 Por. tamże, kan. 312-313. Ze względu za zasięg działalności mogą być: diecezjalne, krajowe, międzynarodowe i powszechne. Por. też M. Delgado Galindo, Asociaciones internacionales de fieles, Ius Canonicum 50 (2010) 1, s. 9-29. 
stowarzyszenia, które jest właściwe duchowości instytutu ${ }^{31}$. Statuty publicznego stowarzyszenia wymagają aprobaty władzy kościelnej32. Prawo kanoniczne ogranicza członkostwo w niektórych sytuacjach: publiczne odstapienie od wiary katolickiej, zerwanie ze wspólnotą kościelną, kara ekskomuniki nałożonej wyrokiem czy zdeklarowanej33. Stowarzyszenia publiczne posiadają moderatora oraz osobę asystenta kościelnego (kapelana) ${ }^{34}$. Stowarzyszenia mogą gospodarować różnymi dobrami zgodnie z postanowieniami statutów; istnieje nadzór władzy kościelnej i sprawozdawczość składana właściwym podmiotom ${ }^{35}$.

Jak już zaznaczono, w prawie kanonicznym odróżnia się stowarzyszenia publiczne od prywatnych. Te drugie często powstają oddolnie z inicjatywy wiernych. Do uzyskania kanonicznego uznania stowarzyszeń prywatnych oraz podmiotowości prawnej w Kościele wymagany jest dekret kompetentnej władzy kościelnej i aprobata statutów ${ }^{36}$. Jedynie za zgodą odnośnej władzy kościelnej mogą się nazywać „katolickimi" ${ }^{37}$. Prywatne stowarzyszenia są kierowane przez samych wiernych, według zapisów statutów ${ }^{38}$. Zachowują one autonomię, co dotyczy np. wyznaczania własnych moderatorów; pozostają jednak zależne od władzy kościelnej, która sprawuje nad nimi nadzór ${ }^{39}$. Stowarzyszenia prywatne w sposób wolny zarządzają posiadanymi dobrami, z zachowaniem prawa nadzoru władzy kościelnej ${ }^{40}$.

31 Por. KPK 1983, kan. 312 § 2. Por. też M. Areitio, Asociaciones y vida consagrada: distintas relaciones y sus perspectivas canonicas, Ius Canonicum 50 (2010) 1, s. 129-161.

32 Por. KPK 1983, kan. 314. Zatwierdzenie statutu jest aktem odrębnym od erygowania stowarzyszenia; często te dwa akty są zawarte w tym samym dokumencie.

33 Por. tamże, kan. $316 \S 1-2$. Oddalenie się od wiary katolickiej łączy się ponadto z takimi sytuacjami, jak: życie w konkubinacie, czy życie tylko w związku cywilnym; statut jest tu punktem odniesienia w sprawach członkowstwa, por. L. NAVARRO, Diritto di associazione e assiociazioni di fedeli, s. 179-181.

34 Por. KPK 1983, kan. 317-318.

35 Por. tamże, kan. 319. Dobra należące do kościelnych osób prawnych publicznych są dobrami kościelnymi, co powoduje, że podlegają także normom księgi piątej Kodeksu z 1983 r. Zasady dotyczące zniesienia stowarzyszeń publicznych, por. tamże, kan. 320.

36 Por. tamże, kan. $299 \S 1-3$, kan. 321-322.

37 Por. tamże, kan. 300.

38 Por. tamże, kan. 321.

39 Por. tamże, kan. 323-324.

40 Por. tamże, kan. $325 \S 1-2$. 
Kościół naucza wiernych, by pośród zwyczajnych warunków życia społecznego tworzyli oni ewangeliczny zaczyn prowadzący do uświęcenia świata ${ }^{41}$. Formą apostolstwa wiernych jest także ich wielorakie zaangażowanie $\mathrm{w}$ stowarzyszenia ${ }^{42}$. Niezależnie od formy prawnej stowarzyszenia prawo kanoniczne zachęca katolików, by doceniali stowarzyszenia. „Wierni świeccy powinni doceniać stowarzyszenia ustanawiane dla celów duchowych, o których w kan. 298, zwłaszcza te, które zmierzają do ożywienia chrześcijańskim duchem porządku rzeczy doczesnych i w ten sposób usilnie dążą do osiągnięcia ścisłego związku między wiarą i życiem"43. Celem tworzenia chrześcijańskiego zaczynu w świecie powstają stowarzyszenia wiernych wewnątrz Kościoła i wyraźnie zależne od prawa kanonicznego. Jak również istnieją liczne stowarzyszenia, które chociaż są niezwiązane z prawodawstwem kościelnym, to w założeniu dążą do ożywiania świata duchem chrześcijańskim ${ }^{44}$. Mogą także istnieć stowarzyszenia „faktyczne", które nie zabiegają o akceptację władz kościelnych albo mają jedynie status organizacji uznanych przez państwo ${ }^{45}$.

\section{Stowarzyszenia wiernych w historii i prawie wlasnym Towarzystwa św. Franciszka Salezego}

Założycielem Towarzystwa św. Franciszka Salezego, tj. instytutu zakonnego kleryckiego na prawie papieskim, był św. Jan Bosko (1815-1888). Głównym celem założyciela i następnie instytutu jest wychowanie oraz ewangelizacja młodzieży ${ }^{46}$. W trakcie swej pracy apostolskiej św. J. Bosko docenił pomoc zaangażowanych ludzi świeckich, a także kapłanów diecezjalnych ${ }^{47}$. Podjął pierwszą for-

${ }^{41}$ Por. Konstytucja dogmatyczna o Kościele Lumen Gentium, w: Sobór Watykański II, Konstytucje, Dekrety, Deklaracje, tekst polski, Poznań 2002, s. 104-166, nr 31.

42 Por. Apostolicam actuositatem, nr 19.

43 KPK 1983, kan. 327.

44 Por. Komentarz do Kodeksu Prawa Kanonicznego, t. II/1, s. 154. Mogą tu być zaliczane m.in. partie chrześcijańskie, czy chrześcijańskie związki zawodowe.

45 Por. M. WróBel, Stowarzyszenia katolickie..., s. 149.

${ }^{46}$ Monografia historyczna nt. św. Jana Bosko i jego dzieł, por. M. WirTH, Ksiadz Bosko i rodzina salezjańska. Dzieje $i$ nowe wyzwania (1815-2000), tłum. T. Jania, Kraków 2009. Również św. Jan Bosko był współzałożycielem sióstr salezjanek, tj. Córek Maryi Wspomożycielki.

${ }^{47}$ Por. P. BRAIDO, Laicita e laici nel progetto operativo di don Bosco, w: Laici nella familia salesiana. Atti della XII Settimana di Spiritualita della Famiglia Salesiana, red. M. Cogliandro, A. Martinelli, Roma 1986, s. 17-34. 
malną próbę zorganizowania współpracowników dzieł wychowawczych, pod nazwą „Pobożnego Zjednoczenia”, jeszcze w $1850 \mathrm{r}^{48}$. Po konsultacjach ze Stolicą Apostolską założył w 1876 r. stowarzyszenie współpracowników, rodzaj salezjańskiego trzeciego zakonu ${ }^{49}$. Stowarzyszenie gromadziło osoby, które nie zmieniając swego stanu w Kościele - wzięły współodpowiedzialność za świat i Kościół w tym samym duchu, co salezjanie.

Pod aktualną nazwą Stowarzyszenie Salezjanów Wspótpracowników współdziała z salezjanami i ma oparcie m.in. w prawie własnym tegoż instytutu zakonnego. Omawiane stowarzyszenie kontynuuje posłannictwo ks. Bosko, trwając w jedności $\mathrm{z}$ innymi podmiotami, które tworzą rodzinę salezjańską ${ }^{50}$. Zakonne wspólnoty salezjańskie mają wspierać Stowarzyszenie, m.in. w zakresie formacji członków i upowszechnianiu tego specyficznego powołania ${ }^{51}$. Stowarzyszenie Salezjanów Wspótpracowników najczęściej współdziała w już istniejących salezjańskich formach apostolstwa ${ }^{52}$.

Do wspomnianej wyżej „rodziny salezjańskiej” należą salezjanie i salezjanki, ale także inne instytuty zakonne i świeckie oraz stowarzyszenia i grupy. Tym, co łączy tę ,rodzinę”, jest: charyzmat św. Jana Bosko, młodzieżowe i ludowe posłannictwo, salezjański styl życia i działania oraz związek z Założycielem rodziny salezjańskiej oraz jego następcami ${ }^{53}$.

48 Por. M. WIRTh, Ksiadz Bosko i rodzina salezjańska, s. 192-195.

49 Por. tamże, s. 196-200. Pius IX wydał 9 maja 1876 r. breve akceptujące stowarzyszenie i jego regulamin.

50 Por. Konstytucje, art. 5.

${ }^{51}$ Por. Regulaminy Ogólne, art. 38; A. MARTinelli, Refleksje po zakończeniu Regionalnych Kongresów Stowarzyszenia Pomocników Salezjańskich, Dokumenty Rady Generalnej (1994) 349, s. 36-44; dla czasopisma „Dokumenty Rady Generalnej” dalej używam skrótu: DRG.

52 Por. Program życia salezjanów Księdza Bosko. Przewodnik po lekturze Konstytucji Salezjańskich, Kraków 1997, s. 89.

53 Por. Program życia salezjanów Księdza Bosko, s. 86; A. Martinelli, Karta jedności rodziny salezjańskiej księdza Bosko, DRG (1995) 353, s. 31-41; J. VECCHI, Rodzina salezjańska kończy 25 lat, DRG (1997) 358, s. 3-38; Uznanie przynależności do rodziny salezjańskiej, DRG (1998) 363, s. 45-52; A. MARTINELLI, Animacja duchowa i duszpasterska grup należacych do rodziny salezjańskiej poparta charyzmatami święceń kapłańskich, DRG (2001) 375, s. 44-55; A. BREGOLIN, Niektóre wskazania dla animacji rodziny salezjańskiej na szczeblu inspektorialnym i lokalnym, DRG (2006) 392, s. 44-48; P. Chavez, List przełożonego generalnego. Rodzina salezjańska wczo- 
Propozycja wychowawcza ks. Bosko okazała się skuteczna i prowadziła do wychowania młodych ludzi na dobrych chrześcijan i zarazem prawych obywateli. Byli wychowankowie Jana Bosko spotykali się ze swoim wychowawca, ale też praktycznie wspierali dzieła salezjańskie ${ }^{54}$. Zrzeszenia byłych wychowanków powstawały również poza Turynem, przy innych dziełach salezjańskich. Stopniowo ruch ewoluował ku zbudowaniu międzynarodowej federacji stowarzyszeń $^{55}$.

Także współcześnie wychowankowie dzieł salezjańskich są zaproszeni do włączenia się w posłannictwo rodziny salezjańskiej. „Byli wychowankowie należą do rodziny salezjańskiej z tytułu otrzymanego wychowania. Ich przynależność staje się bardziej ścisła, gdy zobowiążą się do uczestnictwa w posłannictwie salezjańskim w świecie" ${ }^{56}$. Wspólnota salezjanów powinna utrzymywać kontakty z byłymi wychowankami, okazywać im zainteresowanie, stwarzać okazje do spotkań, formacji i współpracy; a także pobudzać i podtrzymywać Stowarzyszenie Byłych Wychowanków Księdza Bosko i wspólnie z nimi szukać sposobów zbliżenia tych, którzy się oddalili, oraz pomagać w dorastaniu do powołania pomocnika ${ }^{57}$.

Trzecim stowarzyszeniem, które rozwinęło się za życia ks. Bosko, było Stowarzyszenie Maryi Wspomożycielki Wiernych. Jego powstanie wynikało z kultu maryjnego założyciela salezjanów, który był wielkim czcicielem Maryi pod wezwaniem Wspomożycielki Wiernych. Pobożność maryjna przenikała Jana Bosko i wpisała się w charyzmat salezjański. Wyrazem tego kultu był zbudowany przez niego w Turynie kościół Maryi Wspomożycielki. Od początku swego istnienia świątynia promieniowała nabożeństwem pod tym wezwaniem maryjnym $^{58}$. Przy tymże kościele już w 1869 r. powstało Stowarzyszenie Maryi Wspomożycielki Wiernych. Salezjanie współpracują z tym sto-

raj i dziś, DRG (2009) 403, s. 3-32; La Famiglia salesiana di don Bosco, Roma 1999; Laici nella familia salesiana...

54 Por. M. WirTh, Ksiądz Bosko i rodzina salezjańska, s. 368-369.

55 Por. tamże, s. 372-377.

${ }^{56}$ Konstytucje, art. 5. Por. Program życia salezjanów Księdza Bosko, s. 88-89. Komentarzem do art. 5 Konstytucji jest list przełożonego generalnego, por. Lettera del rettor maggiore don Egidio Vigano ai salesiani su exallievi di don Bosco, Roma 1987.

57 Por. Regulaminy Ogólne, art. 39.

58 Por. M. WIRTH, Ksiądz Bosko i rodzina salezjańska, s. 140-142. 
warzyszeniem, jak i innymi instytutami, grupami i ruchami należącymi do „rodziny salezjańskiej”"59.

Piąty artykuł Konstytucji Salezjańskich stanowi o szeroko rozumianym ruchu społecznym, który koncentruje się wokół posłannictwa młodzieżowego. Interpretacja tego zapisu prawa własnego salezjanów nie może zamknąć się w gronie podmiotów formalnie przyjętych do „rodziny salezjańskiej”. Istnieją różne grupy osób odwołujące się do ks. Bosko i jego programu apostolskiego. „Ostatecznie taki ruch może obejmować różnoraką rzeczywistość, nawet grupy mało podobne, o różnych sposobach organizacji oraz odmiennych zapatrywaniach, dotyczących promocji ludzi i opieki społecznej, łącznie z nawiązywaniem współpracy $\mathrm{z}$ niechrześcijanami, a nawet niewierzącymi. Słowem, ruch ten może skupiać wokół ks. Bosko i młodzieży ludzi dobrej woli, którzy nie zawsze musieliby znać podstawy wychowania salezjańskiego, jakimi są: rozum, miłość i religia." ${ }^{60}$

Tym samym z salezjanami mogą współpracować różnorakie stowarzyszenia. Także te, które nie mają kanonicznego charakteru stowarzyszeń wiernych. A po stronie Zgromadzenia Salezjańskiego spoczywa odpowiedzialność nie tylko za ściśle rozumianą „rodzinę salezjańską", ale również za zasygnalizowany szeroki ruch społeczny. Odpowiedzialność polega na utrzymaniu ducha jedności, pobudzaniu do dialogu i braterskiej współpracy dla większej skuteczności apostolskiej ${ }^{61}$. Regulaminy Ogólne stanowią dalej: „wspólnota, w porozumieniu z odpowiedzialnymi różnych grup, w duchu służby i z poszanowaniem ich autonomii, zapewnia im opiekę duchową, zachęca do spotkań, popiera współpracę wychowawczą i duszpasterską oraz rozwija wspólne działanie na rzecz powołań"62. Ten zapis można W szerszej interpretacji odnieść do stowarzyszeń spoza „rodziny salezjańskiej”, które współpracują z salezjanami w wychowywaniu młodzieży.

${ }^{59}$ Por. Konstytucje, art. 5. Wymienione trzy stowarzyszenia i inne, które są związane z rodziną salezjańską, por. A. DomAszK, Realizacja misji nauczycielskiej Kościoła w publicznych stowarzyszeniach wiernych zwiazanych z Towarzystwem Św. Franciszka Salezego, Prawo Kanoniczne 54 (2011) nr 1-2, s. 17-41.

${ }^{60}$ Program życia salezjanów Księdza Bosko, s. 85.

61 Por. Konstytucje, art. 5.

62 Regulaminy Ogólne, art. 36. 


\section{Salezjańskie Stowarzyszenie Wychowania Mtodzieży}

W salezjańskiej inspektorii św. Wojciecha z siedzibą w Pile od roku 1994 rozwijała się działalność Salezjańskiego Ruchu Młodzieżowego. Ruch ten na przełomie roku 2000/2001 przyjął formę stowarzyszenia i funkcjonuje pod nazwą: Salezjańskie Stowarzyszenie Wychowania Młodzieży (dalej SSWM) z siedzibą w Pile, działając na terenie RP. Nastąpiło prawne przeobrażenie $\mathrm{z}$ ruchu młodzieżowego $\mathrm{w}$ stowarzyszenie zarejestrowane 12 listopada 2001 r. w sądzie, pod nr KRS 0000061527.

W dalszym rozwoju powstawały oddziały regionalne SSWM w Bydgoszczy, Szczecinie Wielgowie, Rumi, Nowogródku Pomorskim, Trzcińcu, Aleksandrowie Kujawskim, Czaplinku i Poznaniu. Aktualnie stowarzyszenie liczy 178 członków zwyczajnych ${ }^{63}$. Prawo o stowarzyszeniach przewiduje, że terenowe jednostki organizacyjne mogą uzyskać osobowość prawna, jeżeli statut stowarzyszenia to przewidu$\mathrm{je}^{64}$. Stowarzyszenie zgodnie z prawem polskim posiada własny statut, w którym określa wszystkie istotne elementy i struktury stowarzyszenia. Przewiduje on tworzenie terenowych jednostek, ale zgodnie z decyzją zarządu SSWM nie posiadają one osobowości prawnej ${ }^{65}$.

Działalność statutowa stowarzyszeń niekiedy zbiega się z wykonywaniem zadań publicznych przez struktury państwowe. Zatem, do stowarzyszeń należy zastosować zasadę pomocniczości, w oparciu o którą organizacje pozarządowe wspierają państwo w realizacji zadań publicznych ${ }^{66}$. Takie działania opierają się na Ustawie o działalności pożytku publicznego i o wolontariacie z 2003 r. ${ }^{67}$ Salezjańskie Stowarzyszenie Wychowania Młodzieży 15 kwietnia 2005 r. zostało uznane za Organizację Pożytku Publicznego.

Każde stowarzyszenie ma własne cele. Jakie cele określa dla siebie SSWM? Po wstępie stanowiącym o działalności na rzecz ogółu społeczności, zwłaszcza na rzecz osób będących w trudnej sytuacji

${ }^{63}$ Rys historyczny i liczba członków za: http://www.sswm.org/ (data dostępu: 27.05.2011).

${ }^{64}$ Por. Prawo o stowarzyszeniach, art. 10 ust. 2, art. 17 ust. 1 a.

65 Por. Statut SSWM, § 6; tekst statutu za: http://www.sswm.org/strony-8/statut. htm (data dostępu: 27.05.2011). Decyzja zarządu SSWM; por. http://www.sswm.org/ strony-7/oddzialy_lokalne.htm (data dostępu: 28.05.2011).

${ }_{66}$ Por. H. IzDEBski, Fundacje i stowarzyszenia, s. 22-24.

67 Por. Dz. U. z 2003 r., nr 96, poz. 873. 
życiowej i materialnej, statut SSWM specyfikuje zadania: „charytatywna pomoc społeczna dzieciom, młodzieży i rodzinom będącym w trudnej sytuacji życiowej, wychowanie, opieka i edukacja dzieci i młodzieży, animacja ośrodków salezjańskich do skutecznej pracy wychowawczej w danym środowisku, nawiązywanie kontaktów i współpraca z organizacjami pozarządowymi oraz działania na rzecz integracji europejskiej, upowszechnianie kultury fizycznej, sportu i wypoczynku, ukazywanie osobowej relacji do Boga i promowanie wartości chrześcijańskich, promocja i organizacja wolontariatu"68.

Te ogólne cele statut dookreśla i dzieli na działania nieodpłatne oraz odpłatne. W pierwszej grupie wymienione są następujące formy aktywności stowarzyszenia: ,pomoc w kształceniu się młodzieży ubogiej, organizowanie spotkań integracyjnych dla dzieci i młodzieży, działalność turystyczno-wypoczynkowa, współdziałanie z instytucjami państwowymi, społecznymi, samorządowymi i pozarządowymi, różnorodna pomoc dla dzieci i młodzieży, szczególnie potrzebujących, zwłaszcza pochodzących ze środowisk zagrożonych alkoholizmem i narkomanią oraz rodzin o niskim standardzie ekonomicznym, różnorodne formy zagospodarowania czasu wolnego dzieci i młodzieży, ze szczególnym zwróceniem uwagi na dzieci i młodzież z rodzin ubogich, organizowanie integralnej formacji wolontariuszy, w ramach szkoły animatora (szkolenia, zjazdy, warsztaty), działalność rekreacyjna, kulturalna i sportowa" ${ }^{69}$. Do odpłatnych form aktywności SSWM należą: organizacja cyklicznych spotkań edukacyjnych dla młodzieży, działalność informacyjna, wydawnicza i szkoleniowa, organizacja imprez rozrywkowo-kulturalnych, przygotowanie programów edukacyjnych, promocja wydawnictw z zakresu profilaktyki antyalkoholowej oraz innych wartościowych książek, prasy, filmów, spektakli teatralnych, wystaw, koncertów, itp. ${ }^{70}$ Cele, jakie stawia sobie SSWM, są w wielu punktach zbieżne z zadaniami publicznymi wskazanymi w Ustawie o działalności pożytku publicznego i o wolontariacie ${ }^{71}$.

${ }^{68}$ Statut SSWM, $\S 7$ ust. 1-2.

69 Tamże, $\S 8$ ust. 1.

70 Por. tamże, $\S 8$ ust. 2.

71 „Sfera zadań publicznych obejmuje zadania w zakresie: 1) pomocy społecznej, w tym pomocy rodzinom i osobom w trudnej sytuacji życiowej oraz wyrównywania szans tych rodzin i osób; 2) działalności na rzecz integracji i reintegracji zawodowej i społecznej osób zagrożonych wykluczeniem społecznym; 3) działalności charyta- 
Działalność SSWM koresponduje z celami Zgromadzenia Salezjańskiego. Św. Jan Bosko gromadził młodzież, głównie ubogą. Salezjanie realizują program apostolski swego założyciela, tj. bycie znakami i nosicielami miłości Bożej do młodzieży, zwłaszcza uboższej $^{72}$. To, co Jan Bosko nazywał „oratorium”, zawierało w sobie różne wymiary oddziaływania na młodych ludzi. „Było ono dla chłopców domem, który przygarnia; parafia, która ewangelizuje; szkołą, która przygotowuje do życia i podwórkiem, gdzie spotykają się przyjaciele i żyje się radośnie."73 Salezjańskie oratoria i ośrodki młodzieżowe pełnią zadania ewangelizacyjne oraz wychowawcze, ale też służą młodzieży w rozwoju różnych zainteresowań, jak i w dobrym wykorzystaniu czasu wolnego ${ }^{74}$.

Ze względu na celowe powiązanie SSWM z Towarzystwem Salezjańskim, warto wydobyć ze statutu zapisy, które tę łączność opisują. Już sama nazwa stowarzyszenia podkreśla koherentność: „tworzy się Salezjańskie Stowarzyszenie Wychowania Młodzieży (...)"775. Struktury stowarzyszenia rozwijają się w miejscach, gdzie pracują salezjanie, gdzie istnieją poszczególne domy zakonne. „Stowarzyszenie może powoływać jednostki terenowe - oddziały, obejmujące zasięgiem działania podstawowe jednostki samorządowe, na terenie których istnieją domy zakonne lub parafie Towarzystwa Salezjańskiego Inspektorii pw. św. Wojciecha (...)"’76. Członkowie SSWM są zobo-

tywnej; (... 6) ochrony i promocji zdrowia; (...) 14) nauki, szkolnictwa wyższego, edukacji, oświaty i wychowania; 15) wypoczynku dzieci i młodzieży; 16) kultury, sztuki, ochrony dóbr kultury i dziedzictwa narodowego; 17) wspierania i upowszechniania kultury fizycznej; (...) 19) turystyki i krajoznawstwa; (...) 26) działalności na rzecz integracji europejskiej oraz rozwijania kontaktów i współpracy między społeczeństwami; 27) promocji i organizacji wolontariatu; (...) 31) działalności na rzecz rodziny, macierzyństwa, rodzicielstwa, upowszechniania i ochrony praw dziecka; 32) przeciwdziałania uzależnieniom i patologiom społecznym; (...)", Ustawa o działalności pożytku publicznego i o wolontariacie, art. 4 ust. 1.

72 Por. Konstytucje, art. 2.

73 Tamże, nr 40. Por. M. Wirth, Ksiadz Bosko i rodzina salezjańska, s. 41-106.

${ }^{74}$ Por. Regulaminy Ogólne, nr 11-12.

75 Statut SSWM, § 1. Adres SSWM mieści się w Pile i jest ten sam, co dla salezjańskiej inspektorii św. Wojciecha.

${ }^{76}$ Tamże, § 6. Także prawo własne Inspektorii Św. Wojciecha umiejscawia SSWM wśród swoich dzieł młodzieżowych, por. Dyrektorium inspektorialne Inspektorii Ś $w$. Wojciecha, w: Dokumenty końcowe X Kapituły Inspektorialnej. Ląd nad Wartą 0610 IV 2010 r., Piła 2010, s. 40-115, nr 278-282; prezes oddziału i przełożony lokalnej 
wiązani nie tylko do czynnego udziału w pracach stowarzyszenia, ale również do działalności $\mathrm{w}$ duchu salezjańskim ${ }^{77}$. Najwyższym organem władzy jest Walne Zebranie Członków. Uchwały Walnego Zebrania podlegają kontroli pod kątem zgodności z Konstytucjami Salezjańskimi ${ }^{78}$. Z urzędu członkiem Zarządu SSWM jest Inspektorialny Delegat ds. Duszpasterstwa Młodzieży, który zarazem pełni funkcję prezesa Zarządu ${ }^{79}$. Z kolei w terenowych jednostkach stowarzyszenia, prezes zarządu oddziału musi otrzymać pozytywną aprobatę od dyrektora lokalnej wspólnoty salezjańskiej ${ }^{80}$. Każdy statut stowarzyszenia obejmuje normy na wypadek jego rozwiązania. Przy likwidacji SSWM jego majątek przechodzi na własność Towarzystwa Salezjańskiego Inspektorii pw. św. Wojciecha z siedzibą w Pile ${ }^{81}$.

Zadania SSWM należy odczytać nie tylko w wąskim odniesieniu do Towarzystwa Salezjańskiego, ale znacznie szerzej. Korespondują one ponadto z normami zawartymi w trzeciej księdze Kodeksu Prawa Kanonicznego z 1983 r. Zwłaszcza chodzi tu o kwestię wychowania katolickiego. Wychowanie jest pierwszorzędnym zadaniem rodziców, ale w oparciu o zasadę pomocniczości mogą oni korzystać z różnych środków i instytucji wspierających ${ }^{82}$. Nic nie przeszkadza, aby również stowarzyszenia wspierały rodziny w katolickim wychowaniu dzieci i młodzieży. Należy tu dodać, że wychowanie w myśli katolickiej nie dotyczy tylko przestrzeni religijnej, ale jest integralnym oddziaływaniem. „Ponieważ prawdziwe wychowanie powinno objąć pełną formację osoby ludzkiej, zarówno w odniesieniu do celu ostatecznego, jak i w odniesieniu do dobra wspólnego społeczności, dlatego dzieci

wspólnoty salezjańskiej prowadzą formację duszpasterską wewnątrz stowarzyszenia, por. tamże, nr 282.

77 Por. Statut SSWM, $\S 13$ ust. 2.

78 Por. tamże, § 22 ust. 8; kontroli zgodności dokonuje właściwy inspektor salezjański (Inspektorii Św. Wojciecha w Pile) w terminie 7 dni; zgłoszenie zastrzeżeń powoduje konieczność ponownej debaty nad uchwałą, por. tamże.

79 Por. tamże, $§ 25$ ust. 2-3. Inspektorialny Delegat ds. Duszpasterstwa Młodzieży pełni określone zadania w ramach inspektorii salezjańskiej, por. Dyrektorium inspektorialne, nr 7. Pierwszym Prezesem Salezjańskiego Stowarzyszenia Wychowania Młodzieży był salezjanin ks. Jarosław Pizoń.

${ }^{80}$ Por. Statut SSWM, § 37 ust. 1.

${ }^{81}$ Por. tamże, $\S 43$ ust. 3. Temat likwidacji stowarzyszeń, por. Prawo o stowarzyszeniach, art. 39-39.

${ }^{82}$ Por. KPK 1983, kan. $793 \S 1-2$. 
i młodzież tak powinny być wychowywane, ażeby harmonijnie mogły rozwijać swoje przymioty fizyczne, moralne oraz intelektualne, zdobywać coraz doskonalszy zmysł odpowiedzialności, właściwie korzystać z wolności i przygotowywać się do czynnego udziału w życiu społecznym." 83

Po nakreśleniu celów SSWM i powiązań ze Zgromadzeniem Salezjańskim oraz ogólną misją Kościoła należy pokazać kilka przykładów działalności stowarzyszenia. Stowarzyszenie prowadzi np. wymianę młodzieży, czego efektem jest realizacja założeń edukacji międzykulturowej i rozwijanie zainteresowań uczestników pochodzących z różnych krajów. Od 2007 SSWM angażuje się w międzynarodowy wolontariat: polscy wolontariusze udzielają się poza granicami kraju, a np. włoscy przyjeżdżają do Polski (w ramach współpracy z włoską organizacją La Federazione SCS/CNOS: Servizio Civile Salesiano i Centro Nazionale delle Opere). Organizowane są zloty młodzieżowe. Wydawane jest pismo młodzieżowe pn. „Kontakt” (ISSN 1426-6300) i inne publikacje ${ }^{84}$. Szczegółowe sprawozdania finansowe i merytoryczne z prowadzonej działalności i wszystkich zrealizowanych projektów (w latach 2005-2010) znajduje się na publicznie dostępnej stronie Departamentu Pożytku Publicznego ${ }^{85}$.

Przedstawiając SSWM, można ogólnie zaznaczyć, że zgodnie z Prawem o stowarzyszeniach, SSWM posiada władze, którymi są: Walne Zebranie Członków, Zarząd i Komisja Rewizyjna ${ }^{86}$. Członkami SSWM są osoby fizyczne i osoby prawne (członkowie wspierający) ${ }^{87}$. Statut SSWM składa się z następujących części: postanowienia ogólne, cele i sposoby działania, prawa i obowiązki członków, organy stowarzyszenia, jednostki terenowe SSWM, majątek i fundusze, zmiana statutu i rozwiązanie stowarzyszenia.

83 Tamże, kan. 795.

${ }^{84}$ Informacje o aktualnej i przeszłej działalności stowarzyszenia, por. http://www. sswm.org/ (data dostępu: 08.07.2011).

85 Por. https://bopp.pozytek.gov.pl/opp_pokaz.do;jsessionid=2C8102E9BA60C53EECB44532F834E651?oppId=28927 (data dostępu: 08.07.2011).

86 Por. Prawo o stowarzyszeniach, art. 11 ust. 1-3; Statut SSWM, § 15-28.

${ }^{87}$ Por. Prawo o stowarzyszeniach, art. 3 ust. 1-3, art. 6 ust. 1-2, art. 10 ust. $1 \mathrm{nr} 4$, art. 10 ust. 3; Statut SSWM, § 10-14. 


\section{Salezjański Ruch Troski o Młodzież Saltrom}

Kolejnym przykładem stowarzyszenia o duchowości salezjańskiej jest Salezjański Ruch Troski o Młodzież, który używa skróconej nazwy Saltrom ${ }^{88}$. Działa on na terenie Rzeczypospolitej Polskiej, a siedziba władz znajduje się w Krakowie ${ }^{89}$. Saltrom jest stowarzyszeniem prowadzonym przez pedagogów, wychowawców, salezjanów i wolontariuszy, które prowadzi działalność: wychowawczą, profilaktyczną i edukacyjna.

Ruch na rzecz młodzieży narodził się w krakowskim środowisku salezjanów jeszcze w 1981 roku. „Dom Otwartych Drzwi” stał się schronieniem dla wielu młodych ludzi z ulicy, także narkomanów. Formami udzielanej pomocy były: dożywianie i douczanie, zajęcia terapeutyczne, świetlicowe oraz grupowe. Ruch przekształcił się w stowarzyszenie, które rozpoczęło działalność w 1992 r., wtedy też powstała pierwsza wersja statutu. Stowarzyszenie zostało zarejestrowane w sądzie 30 sierpnia 2002 r. i w związku z tym posiada osobowość prawną (KRS: 0000128589). Saltrom ma od 2005 r. status Organizacji Pożytku Publicznego.

Statut stowarzyszenia po postanowieniach ogólnych oraz wymienieniu celów i sposobów działania reguluje kwestie członkostwa. Członkami Saltromu są osoby fizyczne i osoby prawne (członkowie wspierający). Oprócz członków zwyczajnych i wspierających są też honorowi. Następnie statut przedstawia władze, którymi są: Zjazd Delegatów, Zarząd Główny, Główna Komisja Rewizyjna i Główny Sąd Koleżeński. Statut kończą rozdziały dotyczące majątku Saltromu, zmiany statutu i rozwiązania stowarzyszenia.

Stowarzyszenie może powoływać jednostki terenowe z osobowością prawną ${ }^{90}$. Takie jednostki posiadają struktury analogiczne jak całe stowarzyszenie: walne zebranie, zarząd oddziału, komisja rewizyjna i sąd koleżeński ${ }^{91}$. Całe stowarzyszenie otwiera się na kontakt $\mathrm{z}$ innymi stowarzyszeniami i organizacjami o tym samym lub podobnym profilu ${ }^{92}$.

${ }^{88}$ Por. Salezjański Ruch Troski o Młodzież Saltrom, Statut, Kraków 2005 (dalej Statut Saltrom), art. 1.

${ }^{89}$ Por. tamże, art. 3.

90 Por. tamże, art. 6.

91 Por. tamże, art. 44-66.

92 Por. tamże, art. 5. 
Stowarzyszenie stawia sobie za zadanie aktywnie wychodzić do młodych ludzi i wspierać środowiska młodzieżowe. Chodzi głównie o młodzież zaniedbaną wychowawczo i dysfunkcyjną, zagrożoną moralnie, z uzależnieniami czy po prostu będącą w trudnej sytuacji ${ }^{93}$. Celami wsparcia i pomocy są: kształtowanie postaw religijnych i moralnych, podtrzymywanie tradycji narodowych, obywatelskich i kulturowych, upowszechnianie kultury fizycznej i sportu oraz krajoznawstwa, organizowanie wypoczynku dzieci i młodzieży, promocja zdrowia i ekologii, działalność edukacyjna, oświatowa i wychowawcza, organizowanie szkoleń, zjazdów i kursów, promocja zatrudnienia i aktywizacja zawodowa, szerzenie i organizacja wolontariatu, rozwój kontaktów i współpracy pomiędzy społeczeństwami Europy i świata94.

Tak szerokie spektrum celów wymaga złożonych form ich realizacji. Saltrom wskazuje na następujące: prowadzenie poradni, świetlic, darmowa korepetycja, pomoc medyczna, organizowanie czasu wolnego i wypoczynku dzieci oraz młodzieży, materialne wsparcie dla wychowanków, publicystyka i wydawanie pism, ulotek, organizacja szkoleń, m.in. dla wolontariuszy, współpraca z instytucjami państwowymi, samorządowymi i pozarządowymi ${ }^{95}$.

W realizacji celów Saltrom odwołuje się do religijnej inspiracji. Ze względu na ukierunkowanie na młodzież stowarzyszenie przywołuje św. Jana Bosko, jako przykład wychowawcy, wraz z jego systemem wychowawczym, stylem i metoda pracy ${ }^{96}$. Innymi osobami, które statut wymienia jako wzory i przykłady są: św. Brat Albert, św. Franciszek z Asyżu i bł. August Czartoryski ${ }^{97}$. Stowarzyszenie łączy szczególna więź z Towarzystwem św. Franciszka Salezego, co ma także odzwierciedlenie w samej nazwie. W kontekście Głównego Sądu Koleżeńskiego treść statutu kolejny raz przywołuje system wychowawczy (św. Jana Bosko), który cechuje dobrość, łagodność i cierpliwość. To z kolei implikuje powściagliwość w stosowaniu kar oraz

93 Por. tamże, art. 7 ust. 1.

94 Por. tamże, art. 7 ust. 2.

95 Por. tamże, art. 9.

96 Por. tamże, art. 8. Odwołanie wprost do metody wychowawczej, znanej jako system prewencyjny, por. tamże, art. 2. Opis systemu prewencyjnego ks. Bosko przedstawia strona stowarzyszenia, por. http://www.saltrom.krakow.pl/index.php/o-nas/ system-wychowawczy (data dostępu: 08.07.2011).

${ }^{97}$ Por. Statut Saltrom, art. 8. 
dostrzeganie dobra w każdym z wychowanków ${ }^{98}$. Z chwilą rozwiązania Saltromu majątek stowarzyszenia przechodzi na rzecz inspektorii Towarzystwa Salezjańskiego, na terenie której się on mieści ${ }^{99}$.

Funkcjonowanie Saltromu jest otwarte na pracę profilaktyczną i wychowawczą. Stowarzyszenie w swojej siedzibie prowadzi świetlice dla dzieci: „Świat Dziecka”, oratorium dla młodzieży, kaplicę, jadalnię, salę, w której prowadzone są darmowe korepetycje, salę taneczna, muzyczna, plac zabaw dla najmłodszych, siłownię. Saltrom prowadzi też Placówkę Opiekuńczo-Wychowawczą Wsparcia Dziennego. W okresie zimowym i letnim stowarzyszenie organizuje wypoczynek dzieci i młodzieży. W trakcie rozwoju pojawiły się nowe pomysły przyciagające młodych ludzi: Yacht Club, breakdance, wspinaczka skałkowa, grupy graficiarzy, cheerleaders, taneczne, sportowe i muzyczne ${ }^{100}$. Propozycje ukierunkowane na pomoc dzieciom i młodzieży są otwarte na pomoc wolontariuszy, którzy mogą pomagać np. w korepetycjach. Studenci krakowskich uczelni mają możliwość przeprowadzania swoich praktyk $\mathrm{w}$ ramach różnych działań prowadzonych przez Saltrom. Jeszcze inną propozycją stowarzyszenia stanowi bezpłatny punkt poradnictwa i konsultacji psychologiczno-pedagogicznej $^{101}$. Szczegółowe informacje prowadzonych działań zawierają sprawozdania merytoryczne, które zawierają także dane i rozliczenia finansowe. Rozliczenia z lat 2005-2010 są prezentowane na internetowej stronie Saltromu ${ }^{102}$.

\section{Salezjańska Organizacja Sportowa Rzeczypospolitej Polskiej}

Z inicjatywy salezjanów, sióstr salezjanek i osób świeckich powstało w Polsce stowarzyszenie o charakterze sportowym. Salezjańska Organizacja Sportowa Rzeczypospolitej Polskiej, w skrócie Salos RP, została zarejestrowana jako związek stowarzyszeń kultury fizycznej

98 Por. tamże, art. 42.

99 Por. tamże, art. 71 ust. 3. Należy mieć na uwadze główną siedzibę Saltromu, tj. aktualnie miasto Kraków, więc byłaby to salezjańska inspektoria pw. św. Jacka w Krakowie.

${ }_{100}$ Por. http://www.saltrom.krakow.pl/index.php/o-nas/historia (data dostępu: 08.07.2011).

101 Szczegółowe informacje o prowadzonej działalności i propozycjach Saltromu, por. http://www.saltrom.krakow.pl/ (data dostępu: 08.07.2011).

102 Por. http://www.saltrom.krakow.pl/index.php/o-nas/sprawozdania (data dostępu: 08.07.2011). 
29 czerwca 1992 r. w Warszawie. Dnia 30 września 1996 r. została wpisana pod numerem SKF „B” 62 do rejestru stowarzyszeń i związków sportowych Sądu Okręgowego w Warszawie, a 26 czerwca 2001 r. została wpisana do Krajowego Rejestru Sądowego pod numerem KRS: $21665^{103}$. Podstawowym celem Salosu RP jest rozwijanie wychowawczych, kulturalnych i społecznych aspektów sportu. Wychowanie przez sport inspiruje myśl chrześcijańska i salezjańska tradycja. Salos RP jest członkiem: Polisportive Giovanili Salesiane Internazionale, Polskiego Komitetu Olimpijskiego oraz Krajowej Federacji Sportu dla Wszystkich.

Stowarzyszenie kieruje się ustawą Prawo o stowarzyszeniach. Ze względu na swój sportowy charakter istotnym punktem odniesienia była także ustawa z dnia 18 stycznia 1996 r. o kulturze fizycznej ${ }^{104}$ (aktualnie uchylona), a następnie ustawa z dnia 25 czerwca 2010 r. O sporcie ${ }^{105}$. Organizacja posiada status pożytku publicznego. W preambule statutu następuje deklaracja współdziałania ze Zgromadzeniem Córek Maryi Wspomożycielki i Towarzystwem Salezjańskim. Salos RP działa na terenie Polski, a siedzibą jest miasto Warszawa. Stowarzyszenie jest związkiem stowarzyszeń i osób prawnych ${ }^{106}$.

Statut stowarzyszenia po postanowieniach ogólnych wymienia cele i metody działania. Następnie reguluje kwestie członkostwa, praw i obowiązków członków. Statut przedstawia władze, którymi są: Zjazd Salosu RP, Zarząd Salos RP i Komisja Rewizyjna Salos RP. Dokument kończą zapisy dotyczące finansów i majątku stowarzyszenia, zmiany statutu, rozwiązania stowarzyszenia i postanowienia końcowe.

Członkowie Salosu RP dzielą się na: zwyczajnych, honorowych i wspierających. Członkami zwyczajnymi mogą być stowarzyszenia lokalne i inspektorialne SALOS RP oraz inne chrześcijańskie stowarzyszenia kultury fizycznej posiadające osobowość prawną, które akceptują cele i postanowienia statutu SALOS RP ${ }^{107}$. W tym miejscu widać połączenie struktur Salosu ze Zgromadzeniem Salezjańskim. Przy salezjańskich inspektoriach polskich powstały stowarzyszenia in-

103 Por. http://www.salosrp.pl/o_salosie/historia (data dostępu: 09.07.2011).

104 Por. Dz. U. z 1996 r., nr 25, poz. 113.

105 Por. Dz. U. z 2010 r., nr 127, poz. 857.

106 Por. Statut Salos RP, http://www.salosrp.pl/dokumenty/statut (data dostępu: 09.07.2011), art. 1 ust. 1 .

107 Por. tamże, art. 3 ust. 4 nr 1. 
spektorialne Salosu, a przy domach zakonnych (najczęściej) powstały stowarzyszenia lokalne ${ }^{108}$.

Statutowemu nakreśleniu celów i sposobów działania SALOSU RP towarzyszy nawiązanie do duchowości salezjańskiej i systemu prewencyjnego św. Jana Bosko oraz do dokumentów Soboru Watykańskiego II ${ }^{109}$. Treść statutu kilkakrotnie zawiera połączone słowa: „salezjański sport wychowawczy”, co wyraża nawiązanie do systemu wychowawczego ks. Bosko, a zarazem do idei wychowania przez sport $^{110}$. Należy dodać w tym miejscu, że Jan Bosko od dzieciństwa wykorzystywał zabawy i sport w początkach swego apostolstwa. W jego oratorium sport stanowił ważne narzędzie wychowawcze. Święty wychowawca dostrzegł, że zabawy i ruch są konieczne dla odprężenia młodego człowieka. Wszystko to dokonywało się w klimacie radości i swobody. Była to świadoma formacja fizyczna, ale również moralna. Poprzez zabawy, głównie ruchowe, prowadził on młodzież do radości i do świętości ${ }^{111}$. Posługa wychowawcza i duszpasterska salezjanów zmierza do integralnego rozwoju młodego człowieka ${ }^{112}$, co łączy się m.in. z oddziaływaniem poprzez sport i wychowanie fizyczne. Integralny rozwój, którego częścią jest rozwój fizyczny, jest celem szeroko rozumianego wychowania katolickiego ${ }^{113}$.

Głównymi celami Salos RP są: rozwijanie wychowawczych, kulturalnych i społecznych aspektów sportu, krzewienie humanistycznych i personalistycznych walorów sportu wraz z ideą olimpizmu, podejmowanie i realizowanie przedsięwzięć zmierzających do wychowania

108 Strona główna Salos RP podaje 5 stowarzyszeń inspektorialnych (4 inspektorie salezjanów i jedna sióstr salezjanek) oraz 72 stowarzyszenia lokalne. Salezjanie i salezjanki są wybierani do zarządu Salos RP, jako kandydaci ze stowarzyszeń inspektorialnych, por. Statut Salos RP, art. 5 ust. $6 \mathrm{nr}$ 2. Salezjanin wobec stowarzyszenia lokalnego (członków, wychowawców i trenerów) pełni opiekę duszpasterską, por. Dyrektorium inspektorialne Inspektorii Św. Wojciecha, s. 81, nr 201; delegat ds. duszpasterstwa młodzieżowego wchodzi do zarządu stowarzyszenia inspektorialnego, por. tamże, nr 202.

109 Por. Statut Salos RP, art. 2.

${ }_{110}$ Por. tamże, art. 2 ust. 1 nr 1, art. 3 ust. 1, art. 3 ust. 2 nr 4, art. 3 ust. 5 nr 1, art. 3 ust. $6 \mathrm{nr} 1$.

111 Element sportu w oratorium św. Jana Bosko, por. M. Wirth, Ksiadz Bosko i rodzina salezjańska, s. 96-99. Cechy oratorium salezjańskiego, por. Konstytucje, art. 40.

112 Por. Konstytucje, art. 31-32.

113 Por. KPK 1983, kan. 795. 
i asystencji w procesie wzrastania dzieci i młodzieży, upowszechnianie wychowania fizycznego, sportu, rekreacji ruchowej i turystyki wśród dzieci i młodzieży, propagowanie i umacnianie chrześcijańskich wzorów współzawodnictwa w sporcie i poza nim, organizowanie obozów, rajdów, spływów, wędrówek, imprez sportowych i rekreacyjno-wychowawczych oraz kursów i szkoleń, wzbogacanie kultury fizycznej dzieci i młodzieży o elementy wychowawczo-formacyjne, kulturalno-religijne i socjalno-intelektualne, propagowanie idei wolontariatu w sporcie, prowadzenie działalności sportowo-wychowawczej wśród osób niepełnosprawnych, prowadzenie szeroko rozumianej międzynarodowej działalności sportowo-edukacyjnej wśród młodzieży różnych państw i kultur, a szczególnie w ramach krajów Unii Europejskiej, organizowanie zebrań, odczytów, prelekcji, kursów, konferencji, sympozjów, seminariów oraz prowadzenie wydawnictw i publikacji ${ }^{114}$.

Cele statutowe Salos RP realizuje w różnorodny sposób. Informacje o prowadzonych działaniach zawieraja sprawozdania merytoryczne i finansowe. Przykładowo, ze sprawozdania za rok 2010 wynika, że stowarzyszenie przeprowadziło we wskazanym roku: przygotowanie i udział reprezentacji Salos RP w Światowych Igrzyskach Młodzieży Salezjańskiej (Bosco Cup w Lignano Sabbiadoro we Włoszech w dniach 28 kwietnia do 2 maja 2010), XVIII Ogólnopolskie Igrzyska Młodzieży Salezjańskiej (w Płocku w dniach od 10 do 12 września 2010 r.), imprezy sportowo-rekreacyjne w środowisku wiejskim, w tym m.in. Ogólnopolskie Igrzyska Młodzieży Salezjańskiej w futsalu (w Pieszycach w dniach 5-7.02.2010 r.), szereg masowych imprez sportowych (np. XVII Dni Młodości w Debrznie, Savionalia 2010 - Inspektorialne Dni Młodości w Krakowie, Ogólnopolski Turniej w Piłkę Siatkową dla Dziewcząt i Chłopców w Kielcach, Ogólnopolski Turniej Piłki Siatkowej Chłopców w Ostródzie, Pim - Masowa Impreza Sportowa Dla Dzieci I Młodzieży w Twardogórze, Spartakiada Młodych Minipim 2010 we Wrocławiu), 50 obozów sportowych dla dzieci i młodzieży, obozy dla dzieci i młodzieży z terenów dotkniętych powodzią, Ogólnopolskie Sympozjum Naukowe w Warszawie nt. Kultura fizyczna a globalizacja, publikacja książki pt. Kultura fizycz-

114 Por. Statut Salos RP, art. 2 ust. 1 nr 1-13. 
na a globalizacja, kursy i szkolenia dla trenerów i animatorów, zajęcia pozalekcyjne dla dzieci i młodzieży ${ }^{115}$.

\section{Zakończenie}

Zaprezentowana praca badawcza przybliżyła wybrane stowarzyszenia, obecne w rzeczywistości polskiej, które są zarazem związane z duchowością Towarzystwa św. Franciszka Salezego. Przy ich przedstawieniu wskazano jednocześnie, jak są one strukturalnie złączone z Towarzystwem Salezjańskim oraz jak nawiązują do celów salezjańskich, a zarazem misji całego Kościoła.

Dla nakreślenia pełnego kontekstu istnienia stowarzyszeń w początkowych punktach opracowania ukazano prawo polskie oraz prawo kanoniczne, jak również prawo własne Towarzystwa św. Franciszka Salezego. Przedmiotem badań były następujące podmioty: Salezjańskie Stowarzyszenie Wychowania Młodzieży, Salezjański Ruch Troski o Młodzież Saltrom, Salezjańska Organizacja Sportowa Rzeczypospolitej Polskiej.

Św. Jan Bosko założył trzy grupy zrzeszające wiernych, tj. współpracowników, czcicieli Maryi Wspomożycielki i byłych wychowanków. Wytyczył w ten sposób drogę do współpracy salezjanów z różnymi grupami wiernych. Piąty artykuł Konstytucji Salezjańskich stanowi o szeroko rozumianym ruchu społecznym, który koncentruje się wokół posłannictwa młodzieżowego. Istnieją różne grupy osób odwołujące się do ks. Bosko i jego programu apostolskiego, zrzeszające się w stowarzyszenia, które współpracują z salezjanami. Także te, które nie mają kanonicznego charakteru stowarzyszeń wiernych, a tylko cywilną osobowość prawną. Salezjanie, jak i całe Zgromadzenie Salezjańskie, podejmują odpowiedzialność za tak określone stowarzyszenia poprzez utrzymywanie ducha jedności, pobudzanie do dialogu i braterskiej współpracy dla większej skuteczności apostolskiej skierowanej na dzieci i młodzież.

Istnieją stowarzyszenia rozciągające działalność na całą Polskę (Salos RP), jak i takie, które są związane z określoną inspektorią salezjańską (SSWM, Saltrom), mające jakby mniejszy zakres oddziały-

115 Por. Sprawozdanie Merytoryczne za rok 2010, http://www.salosrp.pl/sites/default/files/dokumenty/sprawozdanie_merytoryczne_salos_rp_rok_2010.pdf (data dostępu: 11.07.2011). 
wania (w znaczeniu geograficznym). Niezależnie od tego wszystkie one podejmują działalność wychowawczą, edukacyjną i ewangelizacyjną dzieci i młodzieży. Dzięki czemu ściśle łączą się z głównym posłannictwem Towarzystwa św. Franciszka Salezego. Istotne jest także to, że przedstawione stowarzyszenia, tak w założeniach statutowych, jak i w praktyce, stosują salezjański system wychowania, znany jako system prewencyjny. Przykładowe stowarzyszenia realizuja ponadto założenia integralnego rozwoju dzieci i młodzieży, co jest jednym z założeń misji Kościoła w zakresie wychowania katolickiego.

Istnienie stowarzyszeń nawiązujących do duchowości określonego instytutu zakonnego stanowi ogromny potencjał służący ludziom i ich rozwojowi. Stowarzyszenia ujawniają wielkie zaangażowanie, wręcz pasję społecznikowską ich członków. Jest to bardzo pozytywne doświadczenie społeczne. Zarazem konieczna jest troska, tak po stronie instytutu, jak i stowarzyszenia, aby zachować bogactwo duchowości, w tym wypadku salezjańskiej. Ponadto istnienie tak specyficznej podgrupy stowarzyszeń jest ciekawym materiałem do dalszych badań, w kontekście prawa o stowarzyszeniach. Zarówno w odniesieniu do prawodawstwa polskiego oraz kanonicznego, jak i zakonnego.

\section{The realization of the mission of the Church in associations connected with the spirituality of the Society of St. Francis de Sales}

Polish legislation respects the law to associate. Among numerous different Polish associations there are also those, which are connected with spirituality and aims of specific religious institutes. One can find, inter alia, the associations relating to Salesian charism. This research paper refers to associations, which exist in Poland, and are connected with spirituality of the Society of St. Francis de Sales. The research is focused on the issue of how the activity of some selected associations refers to the realization of the Society of St. Francis de Sales's aims, and at the same time to the mission of the whole Church.

To outline the whole context of existence of associations, in the initial points of this paper, there have been shown the Polish Law, Canon Law, and also the Society of St. Francis de Sales's Own Law. The following associations were the subject of study: Salesian Organisation of Youth Education, Salesian Movement of Concern for the Youth "Saltrom", Salesian Sport Organization of the Republic of Poland SALOS.

Salesians cooperate with various groups of the faithful, also with the youth mission oriented associations, and with those, which don't have the canonical nature of the faithful associations, but have a civil legal personality. What is important is that those 
associations take up educational and evangelisation activity of children and youth. In this way they are closely related with the principal mission of the Society of St. Francis de Sales. Also significant is the fact that presented associations apply Salesian educational system, also known as preventive, in statutory stipulations, as well as in practice. Furthermore, the introduced associations carry out the stipulations of integral development of children and youth, which is one of the stipulations of the Church mission in the scope of Catholic education.

The existence of associations that refer to the spirituality of certain religious institute constitute the immense potential useful to people and their development. The members of the associations show a great commitment, which is a very positive social experience. To preserve the spiritual wealth, in this case the Salesian one, it is vital to give an attention on both the institute and the association side. In addition, the existence of such specific association subgroup is an interesting matter to further research in the context of Law of Associations. 